Original articles

J. Perinat. Med. 16 (1988)

\section{Assessment of the indication for intrauterine treatment of urinary tract malformations}

\author{
Paul Defoort and Michel Thiery
}

Department of Obstetrics, University of Ghent, Belgium

\section{Introduction}

Antenatal diagnosis using ultrasound has rendered intrauterine intervention feasible in such conditions as hydrocephalus, hydrothorax, ascites, and urinary obstruction. Often pathological fetal conditions of this kind are detected during routine ultrasound examination of asymptomatic pregnant women who have no increased risk of fetal malformation. The feasibility of draining the collection of fluid by single or repeated puncture or by insertion of a shunt does not necessarily guarantee significant improvement in the fetal outcome.

This paper reports a retrospective analysis of 19 cases of fetal urinary tract malformation detected antenatally by ultrasound, in which we deliberately refrained from urinary diversion.

\section{Material and methods}

The analysis covers a consecutives series of 19 fetuses with urinary tract malformation detected or confirmed by our ultrasound unit between 1980 and 1985 (table I). This series is part of a larger one comprising 94 cases of fetal malformation observed in the same unit during that period. No major malformation escaped detection in booked patients during this period. The equipment used was a real time scanner which combined a 3.5 $\mathrm{MHz}$ linear array and a sector probe (ADR/ Kranzbühler 8130/8140, Squibb Medical Systems). The outcome is known for all fetuses, and necropsy was performed on all fetuses and neonates who died.

\section{Curriculum vitae}

Paul Defoort, M.D., was born in 1946. He was graduated from the State University of Ghent, Belgium, in 1971 and specialized in Obstetrics and Gynecology at the same University until 1976. He is currently on the staff of the Department of Obstetrics, University of Ghent. His main field of interest is ultrasonography and its applications to the field of antenatal diagnosis.

We abstained from any interference with the exception of interrupting the pregnancy when this was requested by the parents and considered feasible by us if the length of gestation was appropriate. This policy was based on two considerations. First, the morphologic information about the fetal lesion(s) obtained with ultrasound is limited compared with what one would consider adequate when planning treatment of the neonate or the infant. Second, intervention is undertaken in the belief that the evolution of the lesion and its deleterious effects on the proximal organ (i.e., the kidney) are still in an early stage and will be reversed by decompression. However, it is questionable that any fetal lesion that can be detected by ultrasound can be regarded to be an "early" lesion. Weighing the above considerations against the parental anguish and stress, and even the 
Table I. Data on the present series

\begin{tabular}{|c|c|c|c|}
\hline $\begin{array}{l}\text { Case } \\
\text { no. }\end{array}$ & Diagnosis & $\begin{array}{l}\text { Duration of } \\
\text { pregnancy at } \\
\text { detection } \\
\text { (menstr. wks) }\end{array}$ & $\begin{array}{l}\text { Fetal } \\
\text { survival }\end{array}$ \\
\hline 1 & Prune belly (obstructive), anhydramnios & 28 & 0 \\
\hline 2 & Potter's syndrome (bilateral renal agenesis) & 28 & 0 \\
\hline 3 & Left hydronephrosis and megaureter (obstructed duplicate kidney) & 31 & - \\
\hline 4 & Polycystic dysplastic kidney Oligohydramnios & 32 & 0 \\
\hline 5 & Pyelo-calyceal distention & 37 & + \\
\hline 6 & Pyelo-calyceal distention, right sided & 34 & + \\
\hline 7 & Potter's syndrome (bilateral renal agenesis) & 21 & 0 \\
\hline 8 & Prune belly (obstructive), anhydramnios & 25 & 0 \\
\hline 9 & $\begin{array}{l}\text { Dysplastic horseshoe-kidney, anhydramnios, no bladder filling, no response } \\
\text { to Lasix test }\end{array}$ & 36 & 0 \\
\hline 10 & Megabladder, urinary ascites, hydrocele and polyhydramnios: urethral valves & 34 & + \\
\hline 11 & Prune belly (obstructive), urinary ascites & 22 & 0 \\
\hline 12 & Polycystic-dysplastic kidney, oligo-hydramnios, vitium cordis & 30 & 0 \\
\hline 13 & $\begin{array}{l}\text { Pronounced renal hypoplasia (Potter IIb), anhydramnios, no bladder } \\
\text { filling, diaphragmatic hernia, uterus didelphys }\end{array}$ & 40 & 0 \\
\hline 14 & Prune belly, diaphragmatic hernia, and multiple stigmata: Trisomy 13 & 36 & 0 \\
\hline 15 & Prune belly & 23 & 0 \\
\hline 16 & Unilateral distension, right kidney $(1 \times 2 \mathrm{~cm})$, disappearing & 17 & + \\
\hline 17 & Polyhydramnios, edema, ascites, hydronephrosis: reflux & 29 & + \\
\hline 18 & Prune belly (obstructive) (bladder $07.2 \times 6.5 \times 6.5 \mathrm{~cm}$ ), anhydramnios & 17 & 0 \\
\hline 19 & Potter's syndrome (bilateral renal agenesis) & 18 & 0 \\
\hline
\end{tabular}

possible risk associated with surgical intervention, we concluded that an expectant policy was neither irrational nor unethical.

During the study period considerable experience has accumulated, and as a result at present many criteria are available for the recognition of cases in which treatment would not be expected to be helpful $[7,16]$. These criteria relate to the type of lesion and its effect on kidney function at the time of diagnosis, the chances of fetal survival as determined by lung hypoplasia, associated lesions, karyotype, and the duration of gestation at the time of diagnosis. These criteria were applied in the retrospective analysis of our cases.

It is clear that in utero decompression of urinary obstruction should not be attempted in the mature fetus $[7,16]$. More difficult to answer is the question of the stage of pregnancy in which treatment must be attempted. The general trend in the literature seems to indicate that lesions rated before the 20th week are irreversibly deleterious to the kidney, because division of the metanephrogenic ampulla and formation of the excretory system start to slow down in the 13th or 14th week(s) and this process is completed by the 20 th week [12].

Associated malformations and chromosomal anomalies are frequent $[5,12]$, and are especially important with respect to meaningful survival of the neonate. However, an ultrasonographic search for minor associated anomalies, particularly in the absence of liquor amnii, is often unrewarding.

The type of urinary lesion is of course a major determinant of success. Renal agenesis and extreme hypoplasia (Potter, type IIb) are clearly not amenable to treatment but must be included when an analysis of the benefit resulting from ultrasonic diagnosis is performed in a population of babies. Nor should polycystic kidney disease be treated [11]. On the other hand, therapy is usually unnecessary in cases of stenosis of the pelvi-ureteric junction [11] and is only exceptionally indicated in cases with unilateral lesions [16, 17], namely when the volume of the hydroureter/hydronephrosis threatens fetal wellbeing or impedes the outflow of the contralateral kidney. Nonobstructive forms of prune belly syndrome are not amenable to treatment [2]. 
In the category that can be treated, e.g. fetuses with bilateral obstructive lesions not associated with other malformations, reasonably good kidney function must be anticipated before surgical intervention is attempted. Ultrasonic signs are not very reliable indices for judging kidney function $[4,5,8,9,10]$; the most sensitive test is assessment of fetal natriuria $[3,4]$. Renal function may be considered normal when the concentration of sodium is lower than $50 \mathrm{mMol} / \mathrm{l}$. The crucial factor that determines neonatal survival, i.e., the presence of lung hypoplasia, cannot be reliably assessed antenatally as yet.

\section{Results}

In table II we have listed the occurrence of the above mentioned factors which contraindicated intrauterine treatment in our cases. In each of our cases at least one (and in most instances several) factors were identified that either rendered intrauterine treatment superfluous or precluded its success. Indeed, in bilateral renal agenesis (cases 2, 7 and 19) there is no available treatment and the same holds for extreme hypo- and dysplasia (cases 9 and 13), which cannot be distinguished ultrasonically from renal agenesis. Cases 4 and 12 belong to the category of cystic dysplasias where intervention cannot be beneficial. Furthermore, the dura- tion of pregnancy contraindicated intrauterine therapy in these cases. Cases 3, 5, and 6 had unilateral lesions. Case 16 showed an early, transient, unilateral lesion that was asymptomatic in the neonate. Case 17 was a stable hydronephrosis due to reflux; neither the character of the lesion nor the duration of the pregnancy justified intrauterine treatment. This case was complicated by premature membrane rupture and placental abruption; on these grounds the fetus was delivered by cesarean section and did well (table III).

Without exception, the fetuses with bilateral obstruction developed the full-blown prune belly syndrome. In case 18 , anhydramnios was already established at week 17. At the other end of the scale, case 14 could not be considered for intrauterine therapy because the pregnancy was too far advanced. The prune belly was not caused by obstruction: there was multiple abnormalities and the baby had trisomy 13 . In cases 1 and 15 the prune belly syndrome was non-obstructive. In the first of these, anhydramnios was associated with pulmonary hypoplasia and amnion nodosum, with adhesion to the entire fetal back. In the latter, besides the extreme malformation, renal function was no longer optimal (natriuria $58 \mathrm{mMol} / \mathrm{l}$ ).

Of the cases with obstructive lesions (nos. 8, 10, and 11), no. 11 showed urinary ascites with per-

Table II. Factors considered to contraindicate intrauterine therapy from a retrospective analysis of 19 untreated cases

\begin{tabular}{|c|c|c|c|c|c|c|c|c|c|c|c|c|c|c|c|c|c|c|c|}
\hline Contraindication & case no. & 1 & 2 & 3 & 4 & 5 & 6 & 7 & 8 & 9 & 1011 & 12 & 13 & 14 & 15 & 16 & 17 & 18 & 19 \\
\hline \multicolumn{20}{|l|}{ Type of lesion } \\
\hline Potter's syndrome & & & $\mathbf{x}$ & & & & & $\mathbf{x}$ & & & & & & & & & & & $\mathbf{x}$ \\
\hline Unilateral lesion & & & & $\mathbf{x}$ & & & $\mathbf{x}$ & & & & & & & & & $\mathbf{x}$ & & & \\
\hline Non-evolving lesion & & & & & & $\mathbf{x}$ & $\mathbf{x}$ & & & & & & & & & $\mathbf{x}$ & $\mathbf{x}$ & & \\
\hline Non-obstructive prune belly & & & & & & & & & & & & & & $\mathbf{x}$ & $\mathbf{x}$ & & & & \\
\hline Polycystic dysplasia & & & & & $\mathbf{x}$ & & & & & $\mathbf{x}$ & & $\mathbf{x}$ & $\mathbf{x}$ & & & & & & \\
\hline \multicolumn{20}{|l|}{ Associated lesions } \\
\hline Other malformations & & & & & & & & & & & $\mathbf{x}$ & $\mathbf{x}$ & $\mathbf{x}$ & $\mathbf{x}$ & & & & & \\
\hline Abnormal karyotype & & & & & & & & & & & & & & $\mathbf{x}$ & & & & & \\
\hline \multicolumn{20}{|l|}{ Functional evaluation } \\
\hline Anhydramnios/oligohydramnios & & $\mathbf{x}$ & $\mathbf{x}$ & & $\mathbf{x}$ & & & $\mathbf{x}$ & $\mathbf{x}$ & & & $\mathbf{x}$ & $\mathbf{x}$ & & & & & $\mathbf{x}$ & $\mathbf{x}$ \\
\hline Pathological natriuria & & & & & & & & & & & $\mathbf{x}$ & & & & $\mathbf{x}$ & & & & \\
\hline Bladder calcifications & & & & & & & & & $\mathbf{x}$ & & & & & & & & & & \\
\hline \multicolumn{20}{|l|}{ Duration of pregnancy } \\
\hline Very early lesion & & & & & & & & & & & & & & & & & & $\mathbf{x}$ & $\mathbf{x}$ \\
\hline Late diagnosis & & & & $\mathbf{x}$ & $\mathbf{x}$ & $\mathbf{x}$ & $\mathbf{x}$ & & & $\mathbf{x}$ & $\mathbf{x}$ & $\mathbf{x}$ & $\mathbf{x}$ & $\mathbf{x}$ & & & $\mathbf{x}$ & & \\
\hline \multicolumn{20}{|l|}{ Pathological diagnosis } \\
\hline Kidney dysplasia & & $\mathrm{x}$ & & & $\mathrm{x}$ & & & & $\mathbf{x}$ & $\mathbf{x}$ & & $\mathrm{x}$ & $\mathbf{x}$ & & & & & & \\
\hline Lung dysplasia & & $\mathbf{x}$ & $\mathbf{x}$ & & & & & $\mathbf{x}$ & $\mathbf{x}$ & & $\mathbf{x}$ & & $\mathbf{x}$ & & & & & & $\mathbf{x}$ \\
\hline
\end{tabular}


Table III. Data on the surviving children

\begin{tabular}{lllll}
\hline $\begin{array}{l}\text { Case } \\
\text { no. }\end{array}$ & $\begin{array}{l}\text { Weeks } \\
\text { at birth }\end{array}$ & $\begin{array}{l}\text { Birth weight } \\
(+ \text { centile rank })\end{array}$ & Sex & Evolution \\
\hline 3 & 41 & $\begin{array}{l}2800 \\
(>5<10)\end{array}$ & F & $\begin{array}{l}\text { Surviving; obstructed duplicate kidney removed at 8 months } \\
\text { Doing well }\end{array}$ \\
\hline 5 & 39 & $\begin{array}{l}3250 \\
(>25<50)\end{array}$ & M & $\begin{array}{l}\text { Continued observation } \\
\text { Doing well }\end{array}$ \\
\hline 6 & 40 & $\begin{array}{l}2370 \\
(<2.3)\end{array}$ & F & $\begin{array}{l}\text { Continued observation, right kidney hypoplastic at birth } \\
\text { Doing well }\end{array}$ \\
\hline 10 & 34 & 2520 & $\begin{array}{l}\text { Posterior urethral valves; primary derivation } \\
\text { (extrauterine), secondary corrective surgery }\end{array}$ \\
\hline 16 & 38 & 3100 & Moing well \\
\hline 17 & 29 & $\begin{array}{l}1750 \\
(>75<90)\end{array}$ & $\begin{array}{l}\text { No abnormalities in the neonate (IVP, tomography). } \\
\text { Continued observation planned } \\
\text { Doing well }\end{array}$ \\
\hline
\end{tabular}

sisting urine production as assessed by repeat puncture, but at post-mortem examination, two weeks after diagnosis, this infant displayed extreme renal dysplasia with cartilaginous degeneration and marked pulmonary hypoplasia; moreover, serious cloacal malformation (atypical urethral and rectal communication with vaginal agenesis) was responsible for the obstruction. Case 10 , seen at week 32 , had posterior urethral valves and was treated successfully after birth.

On the basis of the available evidence we may safely conclude that from the moment the diagnosis was established, none of the fetuses in our series would have benefited from intrauterine treatment.

\section{Discussion}

The results reported in the literature show that intrauterine treatment of urinary tract anomalies can only be expected to be successful in carefully selected cases, and such candidates represent only a tiny fraction of those detected at the time of ultrasound examination. McFADYEN [12] mentioned 5 survivals among a total of 11 fetuses treated, but a later report [13] indicated that at the time of writing only one of them was still alive. Thomas [19] noted only one survivor out of
8. BLANE et al. [2] analyzed 9 cases and concluded that only one child would have benefited from intrauterine intervention, and of 29 additional cases reviewed by these authors the tentative benefit ratio was 6/38. According to the experience of CAllen [3, 4] and CAMPBell [5], a 10\% benefit ratio can be expected. This fraction may still include neonates who would have done well without intrauterine treatment, and a long-term beneficial effect on renal function has not yet been established for such children.

It seems obvious that fetal treatment has no place when extrauterine treatment would be timely and feasible, but it is not yet clear at what gestational age treatment should be started and thus regarded as a feasible alternative to interruption of the pregnancy. According to the MANNING registry [11], 11 out of 30 fetuses were treated by vesicoamniotic shunting prior to week 20 . Six of them succumbed, which suggests that the group treated prior to the 20 th week is the most favorable one (6/11 survivals vs. $3 / 8$ before week 25 and $3 / 11$ after week 25). This appears to be at odds with the authors' own conclusion that, in general, "it seems likely that the earlier in gestation the scan occurs, the more overt the disease process must be to be recognized", which corresponds to the experience of others [7, 14, 15]. A possible explanation for this divergence in opinion is that con- 
tributors to MANNING's registry treated some early cases that had not needed any treatment.

Functional evaluation before intervention is still a problem, and visualization of a parenchymatous mantle around a hydronephrotic kidney does not constitute conclusive proof that kidney function is intact [10].

Ultrasonographic clues pointing to integrity of the kidney parenchyma are few and inconsistent. Increased cortical echogenicity denotes dysplasia to some extent [5], but this sign is not wholly reliable [4] because it can be a normal finding in neonates and in infants [8]. The development of oligohydramnios enhances the significance of this sign. Small dysplastic kidneys have a hopeless prognosis.

Urinary volume is an indirect criterion of renal function. Oligo- and anhydramnios, especially when they occur early [1], may signify that the unborn is beyond treatment. If oligohydramnios is seen to develop, this may mean that treatment should be undertaken in cases where other factors are not contraindicating. Normal fluid volume does not mean that renal function is not impaired.

The combination of an empty bladder and dilated kidneys means that renal dysplasia has occurred to a degree that renders any treatment futile [9]. There can be two consequences for the obstructed bladder, either muscular hypertrophy or rupture with consequent spilling of urine into the abdominal cavity of the fetus. The latter event leads to urinary ascites and this may temporarily relieve pressure on the renal parenchyma [18]. Urinary ascites is not always due to rupture but can also result from diffusion of urine through the immature transitional epithelium of the bladder if this is obstructed early in pregnancy [10]. Hypertrophy is present if the wall of the bladder is visible ultrasonographically, which normally is not the case. When intravesical calcifications accompany urinary ascites, the fetal prognosis is hopeless [4].

Analysis of fetal urine (obtained by puncture ) is obligatory for further evaluation of renal func- tion. The assay of creatinine is virtually useless for this purpose, because in large measure the excretory function of the fetus is taken by the placenta. According to DAFFos [6], the fetal creatinine level determined in umbilical blood is related to maternal creatininemia, not to fetal renal function. The most sensitive parameter available is fetal natriuria [3, 4]: renal function can be considered normal when the concentration of sodium is lower than $50 \mathrm{mMol} / \mathrm{l}$. When it is more than $100 \mathrm{mMol} / \mathrm{l}$ the fetus is a salt loser, which means that kidney function has been lost. Between these concentrations there is an intermediate area in which other criteria, based on ultrasonography, should influence the decision concerning treatment.

The most distressing feature of our cases was the high incidence of renal and pulmonary hypoplasia. To put this in perspective, it should be noted that in almost all of the cases (the exception being no. 11, where the parents asked for a two weeks delay, and no. 16, where the lesion was apparently innocent and transient) the pregnancy ended, either spontaneously or was terminated, within the week following final diagnosis. It may be assumed that the findings relating to kidney and lung pathology reflected the situation at the time of diagnosis. In any case, serious treatment programs reportedly require more than a single week of investigations before treatment can be started. It would seem that most cases are already far beyond treatment before they are detected by routine ultrasound examination.

\section{Conclusions}

Retrospective analysis of 19 consecutive cases of fetal urinary tract malformations showed that all of them presented at least one feature which, according to current opinion, renders intrauterine treatment superfluous or futile. In this series, active intervention would not have altered the outcome even in a single case.

\section{Summary}

To assess the potential value of intrauterine diversion in cases of fetal urinary tract malformation, we re-evaluated the 19 cases of such lesions which were part of a consecutive series of 94 cases of fetal malformations that were diagnosed in our department between 1980 and

1985 (table I). We chose a policy of non-interference for two reasons: Firstly the relative paucity of available data compared with what one would normally expect to obtain when planning a treatment of the newborn, and secondly the expectation that the benefit in terms of 
recovery of function would be minimal, because a lesion observable on even early echography is more than trivial, and no longer "early" in an ontogenic sense. The empirical criteria which indicate that intrauterine intervention is either futile or superfluous, noted in the literature, were applied in a retrospective study of our cases and evaluated in relation to the data of pregnancy duration, clinical outcome (tables II and III), and pathological findings in the urinary tract and other systems.

The criteria include: the character of the urinary tract malformation, i.e. incompatible with survival (renal agenesis or aplasia, polycystic dysplasia), benign (unilateral lesion, non-evolving lesions), or those unlikely to be influenced by diversion (non-obstructive lesions); associated lesions or chromosomal anomalies incompatible with possible or meaningful survival; functional parameters, i.a., oligo- or anhydramnios, fetal natriuria indicative of serious renal malfunction, and bladder calcification; pathological findings such us kidney dysplasia which is an irremediable lesion or lung dysplasia incompatible with neonatal survival; and, finally, duration of pregnancy when important early lesions point to a highly compromised fetal situation; or a late diagnosis constitutes an indication for delivery and subsequent postnatal evaluation and treatment.

All of our 19 cases (table II) were found retrospectively to have shown at least one and usually several of these features, each of which is an indication that intrauterine treatment will be either superfluous or useless. We conclude that in the present series a policy advocating intrauterine intervention would not have led to any beneficial change in the outcome.

Keywords: Antenatal diagnosis, fetal treatment, intrauterine intervention, ultrasound, urinary tract malformation.

\section{Zusammenfassung}

\section{Beurteilung der Indikation zur intrauterinen Behandlung von Harntraktmißbildungen}

Um den möglichen Wert einer intrauterinen Urinableitung bei fetalen Harntraktmißbildungen abzuschätzen, bewerteten wir erneut 19 Fälle aus einer konsekutiven Studie von 94 Fällen fetaler Mißbildungen, die in unserer Abteilung von 1980 bis 1985 diagnostiziert wurden (Tabelle I). Wir enthielten uns der Harnableitung aus zwei Gründen: Mangel an Literatur im Verhältnis zu dem, was bei der Planung eines Eingriffes an einem Neugeborenen $\mathrm{zu}$ berücksichtigen ist, und die minimalen Erfolgsaussichten für die Therapie, denn selbst bei früher Untersuchung ist eine im Ultraschall als „ernst“ diagnostizierte Läsion im ontogenetischen Sinne nicht mehr als früh zu bezeichnen. Die empirischen Kriterien aus der Literatur, die eine intrauterine Intervention als sinnvoll bzw. überflüssig erscheinen lassen, wurden retrospektiv auf unsere Fälle angewandt und zur Schwangerschaftsdauer, zum klinischen Bild (Tabellen II und III) sowie zum pathologischen Befund dieser Feten bezgl. Harntrakt und anderer Organe in Beziehung gesetzt.

Die Kriterien lauten: Art der Harntraktmißbildung, d. h. mit dem Leben unvereinbar (Agenesie oder Aplasie der
Nieren, polyzystische Dysplasie), gutartig (einseitige Läsion, nicht-evolutive Läsionen), oder in keiner Art durch eine Harnableitung zu beeinflussen (nicht-obstruktive Läsion); assoziierte Läsionen oder chromosomale Aberrationen, die mit dem Leben unvereinbar sind oder kein sinnvolles Leben ermöglichen; funktionelle Parameter, u. a. Oligo- oder Anhydramnion, fetale Natriurie als Indikator für eine ernste renale Funktionsstörung und Blasenkalzifikation; pathologische Befunde einer Nierendysplasie als Zeichen eines refraktären Organschadens oder eine mit dem Leben unvereinbare Lungendysplasie; und schließlich eine Fortsetzung der Schwangerschaft, nachdem eine ernsthafte frühe Läsion auf einen ausgeprägten Schaden des Feten hingewiesen hat, während nach einer späten Diagnose das Abwarten der Geburt und die postnatale Behandlung indiziert sind.

Bei jedem unserer 19 Fälle (Tabelle II) wurde retrospektiv mindestens eines, meist mehrere, dieser Kriterien gefunden. Jedes einzelne Bedeutet, daß eine intrauterine Behandlung überflüssig oder sinnlos ist. Wir stellen fest, $\mathrm{da} ß$ in dieser Serie eine wohlwollende Einstellung zur intrauterinen Harnableitung keinen positiven Effekt auf die Feten gehabt hätte.

Schlüsselwörter: Antenatale Diagnose, fetale Behandlung, Harntraktmißbildung, intrauterine Harnableitung, U1traschall.

\section{Résumé}

Détermination de l'indication du traitement intra-utérine dans les cas de malformations urinaires

Comme indicateur de la valeur potentielle des dérivations in utéro dans les cas de malformations urinaires, nous avons évalué rétrospectivement 19 cas. Ces cas font partie d'une série consécutive de 94 malformations diverses, diagnostiquées par ultrasons dans notre service de 1980 à 1985 (tableau I). A l'origine nous avions pris l'option de nous abstenir des dérivations in utéro, pour deux considérations. Premièrement, il y a disproportion entre le peu de données que l'on jugerait raisonnable d'obtenir avant d'intervenir ex-utéro sur le même enfant. Deuxièmement, nous sommes d'opinion qu'une lésion apparente à l'échographie, même, et surtout, tôt dans la grossesse, ne peut nullement être considérée minimale au sens ontogénique. Le retentissement organique est déjà important et ne laisse pas préjuger favorablement quant aux possibilités de récupération de l'organe, même 
en cas de décompression. Dans la période couverte par notre étude, la littérature a fait émerger de nombreux critères empiriques qui permettent de juger une intervention intra-utérine, selon le cas, inutile ou superflue. Nous avons confronté ces critères avec les suites cliniques et l'examen pathologique dans nos cas (tableaux II et III). Parmi ces critères: le caractère de la lésion urinaire incompatible avec la survie (agénésie ou aplasie rénale, dysplasies polycystiques), ou par contre bénigne (lésion unilatérale, lésion non évolutive) ou récalcitrant au traitement par la dérivation (lésions non obstructives, tel le reflux); lésions associées ou anomalies du karyotype, incompatibles avec la survie à moyen ou court terme; paramètres fonctionnels, e. a. l'oligo- ou anhydramnios, la natriurie foetale en excès de 50 à $100 \mathrm{mMol} / 1$, indicatifs d'un déficit fonctionnel important du rein, calcification de la vessie; dysplasie rénale indicative de lésions organiques irrécupérables; hypoplasie pulmonaire incompatible avec la survie néonatale; en dernier lieu, la durée de la grossesse, soit en cas d'une lésion importante en début de grossesse démontrant une situation fœtale fort compromise, soit en cas d'un diagnostic tardif rendant indiqué la naissance programmée et l'évaluation et traitement néonatal.

Dans chacun de nos 19 cas, (tableau II) nous notons la présence d'au moins un et dans la plupart de plusieurs de ces critères, rendant en soi le traitement intra-utérin superflu ou inutile. Nous concluons que la dérivation intra-utérine n'aurait pas introduit une change positive dans le résultat fotal dans ces cas.

Mots-clés: Dérivation in utéro, diagnostic anténatal, malformation urinaire, traitement fœtal, ultrason.

Acknowledgements: We thank Dr. N. Lutz-Detringer, from the Department of Pediatrics (Prof. Dr. J. LeRoy) for the German text of the summary.

\section{References}

[1] Barss VA, BR Benacerraf, FD Frigoletto: Second trimester oligohydramnios, a predictor of poor fetal outcome. Obstet Gynecol 64 (1984) 608

[2] Blane CE, SA Koff, RA Bowerman, M BarR: Nonobstructive fetal hydronephrosis: sonographic recognition and therapeutic implications. Radiology $147(1983) 95$

[3] Callen W: Fetal urinary malformations. Communication, Int. Symposium on Fetal Congenital Malformations. Antwerp 1984

[4] Callen W: Feto-amniotic derivations. Communication. Symposium International de Médecine Fœtale. Brussels 1985

[5] CAMpbell S: Abnormalities of the urinary system. Communication, Symposium International de Médecine Fotale. Brussels 1985

[6] DafFos D: Prélèvement de sang fotal sous contrôle échographique. Communication, Symposium International de Médecine Fœtale. Brussels 1985

[7] Golbus MS, MR Harrison, RA Filly: Prenatal diagnosis and treatment of fetal hydronephrosis. Semin Perinatol 7 (1983) 102

[8] Haller Jo, WE Berdon, AP Friedman: Increased renal cortical echogenicity: a normal finding in neonates and infants. Radiology 142 (1982) 173

[9] Harrison M, R. Filly, JF Parer, M Faer, JB JACOBSON, AA DE LORIMIER: Management of the fetus with a urinary tract malformation. JAMA 246 (1981) 635

[10] HaRrison MR, MS Golbus, RA Filly: The unborn patient. Prenatal diagnosis and treatment. Grune and Stratton, Orlando 1984

[11] Manning FA, IR Lange, I Harrison, C Harman: Treatment of the fetus in utero: evolving concepts. Clin Obstet Gynecol 27 (1984) 378
[12] MCFADYEN IR: Obstruction of the fetal urinary tract: a role for fetal intervention in utero? $\mathrm{Br}$ Med J 288 (1984a) 459

[13] MCFADYEN IR: Obstruction of the fetal urinary tract: a role for fetal intervention in utero? $\mathrm{Br}$ Med J 288 (1984b) 1454

[14] MCFadyen IR, JS Wigglesworth, MJ Dillon: Fetal urinary tract obstruction: is active intervention before delivery indicated? Br J Obstet Gynaecol 90 (1983) 342

[15] Nijmegen, Working Group on Antenatal Diagnosis and Therapy. Antenatal diagnosis and treatment with ultrasound (Dutch). Ned Tijdschr Geneeskd 122 (1984) 2073

[16] Petres RE, FO Redwine: Ultrasound in the intrauterine diagnosis and treatment of fetal abnormalities. Clin Obstet Gynaecol 25 (1982) 753

[17] SchaAps JP, H ThOumsin, R LAMBotTE: Intrauterine unilateral nephrostomy. Am J Obstet Gynecol 146 (1983) 105

[18] SMYTHE AR: Ultrasound detection of fetal ascites and bladder dilatation with resulting prune belly. $\mathrm{J}$ Pediatr 35 (1981) 978

[19] Thomas DFM, loc. cit. McFadyen 1984b

Received January 2, 1987. Accepted March 27, 1987.

Michel Thiery, MD, PhD

Professor and Director

Academisch Ziekenhuis

De Pintelaan 185

B-9000 Ghent, Belgium 